\title{
EFFECT OF POST-EMERGENT HERBICIDES APPLICATION ON CAROTENOID CONCENTRATION IN GREEN CORN
}

\author{
SARA DE ALMEIDA RIOS ${ }^{1}$, DÉCIO KARAM ${ }^{2}$, ALUÍZIO BORÉM ${ }^{3}$, \\ WILTON SOARES CARDOSO ${ }^{4}$ and MARIA CRISTINA DIAS PAES ${ }^{2}$
}

\author{
${ }^{1}$ Embrapa Produtos e Mercado,Brasília,DF,Brasil, sara.rios@embrapa.br; \\ ${ }^{2}$ Embrapa Milho e Sorgo, Sete Lagoas, MG,Brasil, decio.karam@embrapa.br, cristina.paes@embrapa.br; \\ ${ }^{3}$ Universidade Federal de Viçosa, Viçosa, MG,Brasil, borem@ufv.br; \\ ${ }^{4}$ IFES (Campus Venda Nova), Venda Nova do Imigrante, ES, Brasil, wilton.cardoso@ifes.edu.br
}

Revista Brasileira de Milho e Sorgo, v.15, n.2, p. 262-271, 2016

\begin{abstract}
Considering the influence of herbicides in the metabolism of the carotenoids in corn, the objective of the present study was to evaluate the effect of herbicides and genotype on carotenoids concentration. The green corn hybrids BRS 1030 and P30F53 were subjected to a post-emergent herbicides application at 20 and 30 days after emergence. Carotenoids were extracted from corn grains and analyzed to quantify $\alpha$ - and $\beta$-carotene, lutein, zeaxanthin, $\beta$-cryptoxanthin, total carotenoids (TC), and total of vitamin A carotenoids precursors (proVA). The application of foramsulfuron + iodosulfuron-methyl-sodium $\left(40+2.6 \mathrm{~g} \mathrm{ha}^{-1}\right)$, nicosulfuron $\left(20 \mathrm{~g} \mathrm{ha}^{-1}\right)$, mesotrione $\left(120 \mathrm{~g} \mathrm{ha}^{-1}\right)$ and tembotrione ( $80 \mathrm{~g} \mathrm{ha}^{-1}$ and $\left.100 \mathrm{~g} \mathrm{ha}^{-1}\right)$ promoted higher concentration of carotenoids in fresh green corn. Lutein, zeaxanthin, $\beta$-cryptoxanthin, $\beta$-carotene, $\alpha$-carotene, proVA carotenoids, and TC concentration increased after foramsulfuron + iodosulfuron-methyl-sodium in late application (V5 to V6), nicosulfuron in both applications, mesotrione applied post-initial (V3 to V4), tembotrione (100 g ha-1) in both applications and tembotrione (80 $\mathrm{g}$ ha $\left.\mathrm{g}^{-1}\right)$ in late post-application, at least for one hybrid. The content of carotenoids in the green corn kernels differed between 'BRS 1030' and 'P30F53'. Our results suggest a possibility of significant increase of carotenoids in green corn kernels through the handling of corn production with post-emergent herbicides.
\end{abstract}

Key words: Zea mays, carotenoid biosynthesis, carotenes, vitamin A, herbicide.

\section{A APLICAÇÃO DE HERBICIDAS PÓS-EMERGENTES INFLUENCIA A CONCENTRAÇÃO DE CAROTENOIDES EM MILHO VERDE}

RESUMO - Considerando a influência dos herbicidas no metabolismo de carotenoides em milho, o objetivo foi avaliar o efeito dos herbicidas e do genótipo na concentração de carotenoides. Os híbridos de milho verde BRS 1030 e P30F53 foram submetidos à aplicação de herbicidas aos 20 e aos 30 dias após a emergência. Os carotenoides foram extraídos dos grãos e analisados para quantificar $\alpha$-caroteno, $\beta$-caroteno, luteína, zeaxanthina, $\beta$-cryptoxanthina, carotenoides totais (CT) e total de carotenoides precursores de vitamina A (proVA). As aplicações dos herbicidas foramsulfuron + iodosulfuron-methyl-sodium $\left(40+2.6 \mathrm{~g} \mathrm{ha}^{-1}\right)$, nicosulfuron $\left(20 \mathrm{~g} \mathrm{ha}^{-1}\right)$, mesotrione $\left(120 \mathrm{~g} \mathrm{ha}^{-1}\right)$ e tembotrione $\left(80 \mathrm{~g}^{-1}\right.$ and $\left.100 \mathrm{~g} \mathrm{ha}^{-1}\right)$, aplicados em mistura com atrazine $\left(1.000 \mathrm{~g} \mathrm{ha}^{-1}\right)$, promoveram aumento da concentração de carotenoides em grãos de milho verde. Luteína, zeaxantina, $\beta$-cryptoxantina, $\beta$-caroteno, $\alpha$-caroteno, proVA carotenoides e CT em grãos de milho verde aumentaram após foramsulfuron + iodosulfuron-methyl-sodium na aplicação tardia (estágios V5 a V6), nicosulfuron em ambas as aplicações, mesotrione aplicado pós-inicial (V3 a V4), tembotrione (100 g ha $\left.{ }^{-1}\right)$ em ambas as aplicações e tembotrione $\left(80 \mathrm{~g} \mathrm{ha}^{-1}\right)$ na aplicação tardia, pelo menos em um dos híbridos avaliados. $\mathrm{O}$ teor de carotenoides nos grãos de milho verde diferiu entre 'BRS 1030' e 'P30F53', indicando o efeito do genótipo na biossíntese destes compostos. Os resultados sugerem a possibilidade de aumento significativo de carotenoides em grãos de milho verde por meio do manejo da produção de milho com os herbicidas pós-emergentes.

Palavras-chave: Zea mays, biossíntese de carotenoides, carotenos, vitamina A, herbicidas. 
The weed control is an important practice for obtaining high yields, once productivity and economics in the production of major crops is limited by the interference of weeds, which tend to increase the cost of production, reducing profit margins and product quality (Constantin \& Oliveira Júnior, 2005).

Maize, despite of being considered competitive and belong to the group of cultures that more shade the soil, suffers intense weed competition, with serious damage on growth, yield and harvesting operation (López-Ovejero et al., 2003). Therefore, the use of herbicides is a necessity of economic order, ensuring fast and efficient control of weeds.

Herbicides, acting as inhibitors or stimulants in important metabolic and physiological pathways for plants, can be strategically used to enhance the accumulation of specific substances. One of the metabolic pathways affected by the herbicides is the biosynthesis of carotenoids.

The first step in carotenoid biosynthesis pathway (Fig. 1) is the condensation of two molecules of geranylgeranyl pyrophosphate (GGDP) to produce 15-cis-phytoene, by phytoene synthase (PSY), which is subsequently converted to its trans isomer (Kim \& Dellapenna, 2006; Li et al., 2007). The phytoene desaturase (PDS) and $\zeta$-carotene desaturase (ZDS) catalyze the dehydrogenation reaction, introducing four double bonds to form lycopene, whose transformation in the trans-isomer is dependent of the carotene isomerase enzyme (CRTISO). Although shown sequentially, there is no evidence that CRTISO act together with ZDS. The desaturation requires an electron transport chain, so the lycopene cyclase catalyzes the cyclization step, with ring formation at both ends of the trans-lycopene chains to form carotenes. These can undergo hydroxylation with consequent production of xanthophylls (Kim \& Dellapenna, 2006; Li et al., 2007).

Some chemical groups recommended for weed control in corn production, such as triketones, act inhibiting the biosynthesis of carotenoids (Karam \& Oliveira, 2007). The inhibition is indirect, since it causes depletion of the cofactor of phytoene dehydrogenase, the enzyme that converts phytoene to phytofluene, step required to the production of lycopene, a precursor of carotenoids in corn (Schultz et al., 1993). This can raise concern for corn breeders, whose programs aimed at increasing or maintaining carotenoids concentration in the grains through biofortification, a complementary tool to reduce nutritional deficiencies in the population that has corn as a staple food, mainly vitamin A. However, results of recent studies indicate that mesotrione and atrazine can enhance the carotenoids lutein and zeaxanthin in sweet corn kernels (Kopsell et al., 2009), although the mechanism of this action is until unclear and requires further studies.

The carotenoids present in the corn grain are divided into carotenes ( $\beta$-carotene and $\alpha$-carotene) and xanthophylls (lutein, $\beta$-cryptoxanthin and zeaxanthin), with higher concentrations of lutein and zeaxanthin compared to other carotenoids (Kurilich \& Juvik, 1999). These compounds are associated to the prevention of cancer, cardiovascular diseases, and vitamin A deficiency (FAO, 2002; Ge et al., 2013; Vallabhaneni \& Wurtzel, 2009; Yao et al., 2013). Considering the importance of carotenoids to human health and because it is unclear why the herbicides affect the levels of these compounds, this study evaluated responses on carotenoid composition of different genotypes of green corn to the post- 
emergent herbicide applications.

\section{Material and methods}

Two corn hybrids (BRS 1030 and P30F53) showing distinguished sensitivity to post-emergent herbicides were evaluated in the present study. 'BRS 1030 ' is considered tolerant while 'P30F53' moderately sensitive, according to evaluations performed seven days after the application of post-emergentherbicides by Karam et al. (2008). The planting of the hybrids P30F53 and BRS 1030 was conducted at the experimental farm of Embrapa Maize and Sorghum, Sete Lagoas/

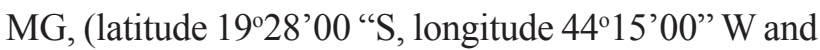
altitude of $732 \mathrm{~m}$ ) at the year 2007. The fertilization was performed using NPK 8-28-16 + Zn $400 \mathrm{~kg} \mathrm{ha}^{-1}$, and $90 \mathrm{~kg} \mathrm{ha}^{-1}$ of $\mathrm{N}$ topdressing 40 days after planting.

Applications of post-emergent herbicides were made at 20 and 30 days after emergence, when corn plants were at stage V3 to V4 (application in early post-emergence - here also called initial) and V5 to V6 (application in late post-emergence), respectively (Magalhães et al., 2002). The applications were done in the morning with the relative humidity of $61 \%$ and air temperature of $30^{\circ} \mathrm{C}$ during the first application and $65 \%$ and $28^{\circ} \mathrm{C}$ for the second one. The hybrids were subjected to the following treatments: (1) control without herbicide application (hand weeding at the time of application of chemical formulations); (2) foramsulfuron + iodosulfuron-methyl-sodium (40 $+2.6 \mathrm{~g} \mathrm{ha}^{-1}$ ) application at 20 days after emergence (initial) and (3) foramsulfuron + iodosulfuron-methylsodium application at 30 after emergence (late); (4) nicosulfuron (20 $\left.\mathrm{g} \mathrm{ha}^{-1}\right)$ in post-emergence (initial) and (5) nicosulfuron in late post-emergence (late); (6) mesotrione (120 $\left.\mathrm{g} \mathrm{ha}^{-1}\right)$ in early post-emergence (initial) and (7) mesotrione in late post-emergence; (8) tembotrione $\left(100 \mathrm{~g} \mathrm{ha}^{-1}\right)$ in early post-emergence (initial) and (9) tembotrione in late post-emergence; and (10) tembotrione $\left(80 \mathrm{~g} \mathrm{ha}^{-1}\right)$ in late post-emergence.

All herbicides (treatments) were applied in combination with atrazine at $1,000 \mathrm{~g} \mathrm{ha}^{-1}$, using a $\mathrm{CO}_{2}$ pressurized backpack sprayer $\left(2.15 \mathrm{kgfcm}^{-2}\right)$, equipped with nozzle-type XR TeeJet 11002 VS, applying the equivalent of $150 \mathrm{~L} \mathrm{ha}^{-1}$. The field experiment was conducted in a randomized block design with four replications. The plots consisted of four rows, 10 meters long, spaced $0.90 \mathrm{~m}$ between rows, and a final stand of approximately 55,000 plants per hectare.

Ten ears were randomly harvested at the reproductive stage R3 (Magalhães et al., 2002), from the central area of each plot (two rows of four meters), which were placed in paper bags and taken to the laboratory. For this purpose, the sample was harvested only in two replications of the field plots. Kernels were removed from the ears with a stainless knife, piled evenly on a clean surface, flattened and spread into a circle. The sample was quarterly according to Rodriguez-Amaya \& Kimura (2004) and two diametrically opposite quarters were discarded. Remaining two quarters were remixed. This procedure of quartering (Kim \& Dellapenna, 2006) was repeated until the sample size was reduced to approximately $250 \mathrm{~g}$. The final sample was homogenized in a blender (model Osterizer, Oster, USA) and then stored in glass vials, sealed with paraffin film and covered with aluminum foil. These samples remained stored in a freezer at $-20{ }^{\circ} \mathrm{C}$ until the chemical analyzes performed in duplicate.

Carotenoids were extracted in a sequential scheme with organic solvents and quantified according to the protocol described by Kurilich \& Juvik (1999) and lutein, zeaxanthin, $\beta$-cryptoxanthin, $\alpha$-carotene and $\beta$-carotene quantified by high performance liquid chromatography (HPLC) in a liquid chromatograph 
Shimadzu LC-10 equipped with polymeric YMC C 30 (5 um, 4.6 x 250 mm, Waters, Milford, MA, USA) coupled to a diode array detector. The gradient of elution was performed at $0.8 \mathrm{~mL} \mathrm{~min}^{-1}$ under conditions of linear gradient 80:20 to 15:85 of methanol: methyl tert-butyl ether for 25 minutes, followed by constant $80: 20$ for $5 \mathrm{~min}$, ending with 6-minute of equilibrium. The laboratory temperature was maintained at $22{ }^{\circ} \mathrm{C}$ throughout the process. For identification of the compounds, standards curves were created using standards purified from natural sources (carrot and corn) following the protocol described by Rodriguez-Amaya \& Kimura (2004).

The sum of all carotenoids quantified in the sample resulted in values of total carotenoids (TC). The total of carotenoids with pro-vitamin A activity (Pro VA) was obtained by the sum of total $\beta$-carotene $+1 / 2$ of the total $\alpha$-carotene $+1 / 2$ of total $\beta$-cryptoxanthin $\left(\mu \mathrm{g} \mathrm{g}^{-1}\right.$ ), considering $100 \%$ of provitamin activity for $\beta$-carotene and $50 \%$ for the other two compounds Rodriguez-Amaya \& Kimura (2004).

The experimental design used in the laboratory was a randomized blocks factorial 2 x 10 (hybrids $\mathrm{x}$ herbicides) totaling 20 treatments with two replications and two laboratory replicates. Data were subjected to analysis of variance (ANOVA) and means were compared by Tukey test at 5\% probability using the Genes program v. 2009.7.0 (Cruz, 2006).

\section{Results and discussion}

Green kernels of 'BRS 1030' and 'P30F53' differed in the composition of carotenoids (Tables 1 and 2). The hybrid P30F53 presented higher concentration of lutein and lower concentration of zeaxanthin in the green kernels compared to 'BRS 1030' (Table 1). This was also observed for all the herbicide treatments, characterizing the effect of genotype in the profile of these compounds $(\mathrm{p} \leq 0.05)$.

Treatment with foramsulfuron + iodosulfuronmethyl-sodium under late application (V5 to V6), nicosulfuron in both applications, mesotrione applied in post-initial (V3 to V4), tembotrione (100 $\left.\mathrm{g} \mathrm{ha}^{-1}\right)$ at both applications and tembotrione $\left(80 \mathrm{~g} \mathrm{ha}^{-1}\right)$ in late post-application resulted in higher concentration of lutein, zeaxanthin, $\beta$-cryptoxanthin, $\beta$-carotene, $\alpha$-carotene, carotenoids Pro VA and TC in kernels of at least one of the hybrids evaluated (Tables 1 and 2).

The difference in concentration of these carotenoids may be related to the intermediate sensitivity of this genetic material to the herbicides application and to the possibility of more copies of genes involved in carotenogenesis. Kopsell et al. (2009) reported that the most significant effect on the concentration of carotenoids with post emergence herbicides application is checked in moderately susceptible cultivars, differently from sensitive hybrids (where the hypersensitive response is irreversible) and tolerant materials (where occurs a rapid metabolism of the products in inactive compounds) plants.

In this study, the average of carotenoids of importance to human nutrition, for both hybrids (Tables 1 and 2) were superior to those reported by USDA (2013), which lists means of $6.44 \mu \mathrm{g} \mathrm{g} \mathrm{g}^{-1}$ of lutein + zeaxanthin and $0.47 \mu \mathrm{g} \mathrm{g}^{-1}$ of $\beta$-carotene, for yellow sweet corn. The elite lines of the Brazilian corn biofortification program coordinated by Embrapa (Brazilian Agriculture Research System) show a variation of $10.83 \mu \mathrm{g} \mathrm{g}^{-1}$ to $42.84 \mu \mathrm{g} \mathrm{g}^{-1}$ for TC in whole mature kernels (Cardoso et al., 2009). Although the levels found in this study were lower, it is important to emphasize that the most important 


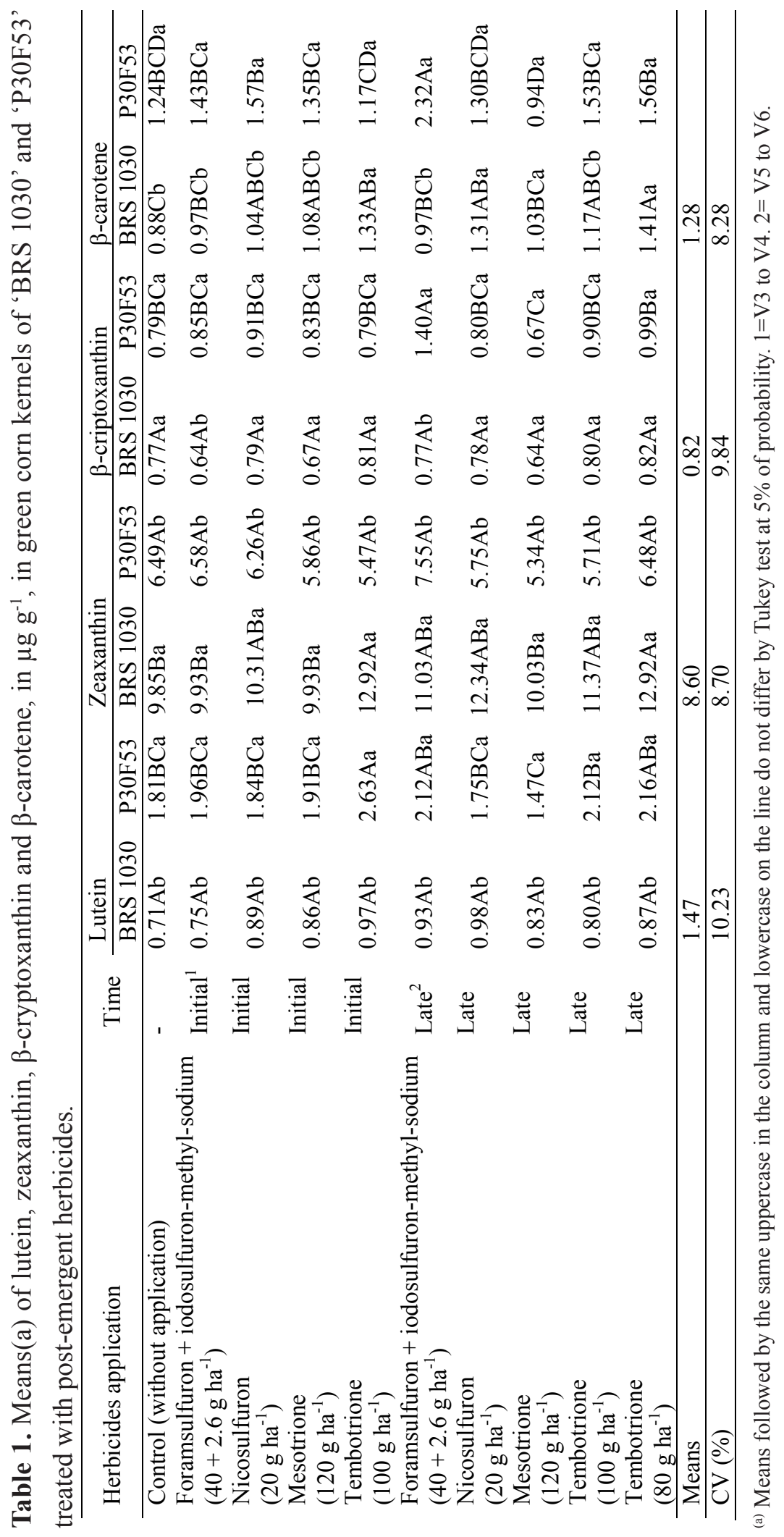




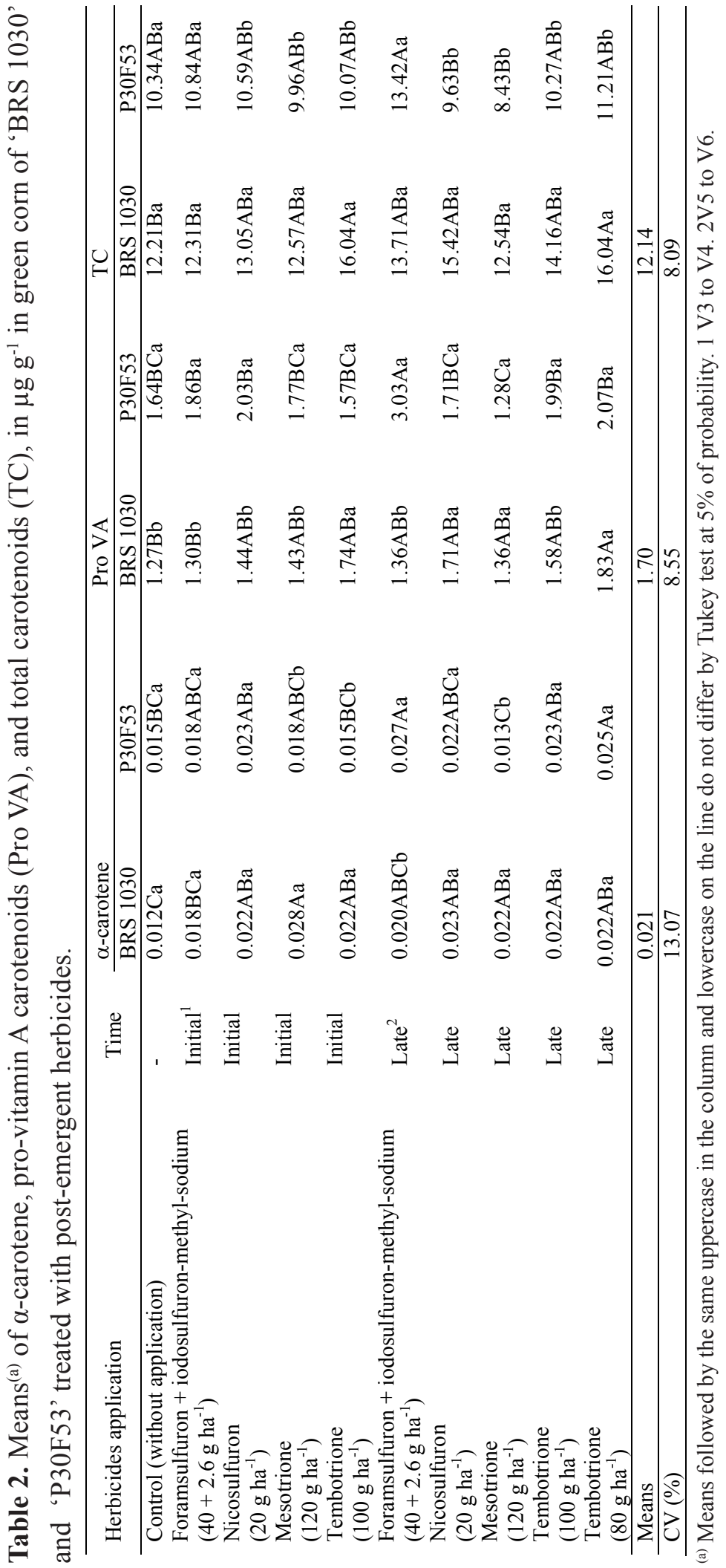


result of this work is not the concentration of carotenoids in the analyzed genetic material but the possibility of treatment of the corn with herbicides cause modification in the kernel composition regarding compounds of biological importance for human health and nutrition.

Corn is tolerant to triketones herbicide group (mesotrione and tembotrione) (Mitchell et al., 2001; Pataky et al., 2008) which act in weeds by inhibiting the biosynthesis of carotenoids. However, considering that this tolerance is related to the concentration of carotenoids in the leaves, and that there is no information about the effect on grains, mainly utilizing another herbicides group, we hypothesize that this application could even reduce the carotenoids concentration. Another important result of this work is that the application of these two herbicides and also for the others tested in this study did not reduce the levels of carotenoids in the green corn kernels when compared to the control $(\mathrm{p} \leq 0.05)$ (Tables 1 and 2).

The tolerance of the corn to the herbicide belonging to the chemical group of the triketones - inhibitors of the enzyme 4-hydroxyphenylpyruvate dioxygenase (HPPD) - is related to the ability of the species to rapidly metabolize the herbicide, mainly due to the action of cytochrome P-450 (Mitchell et al., 2001; Pataky et al., 2008), producing inactive compounds for corn and active to the weeds. This happens also because carotenoid biosynthesis occurs by two different routes (one is the route of the mevalonate and the other is the non-mevalonate).

The accumulation of carotenoids continues until the plant respond to the herbicide (Schwender et al., 1996; Lichtenthaler et al., 1997; Pizarro \& Stange, 2009). It seems that this response may be faster than occurs a conversion for inactive compounds with no time for the accumulation of phytoene, or can be rel- atively slow allowing a significant accumulation of phytoene by herbicide action that blocks the activity of the enzyme PDS, thus preventing the conversion of phytoene to lycopene (Kopsell et al., 2009). In the latter case, after exposure to stress and plant response to this stress, it is likely that compensation occurs in the conversion of the stock of phytoene formed with maximum activity in the PDS which leads to a larger pool of carotenoids (Kopsell et al., 2009). This could be verified in this experiment since there was an increase in the levels of lutein using the tembotrione $\left(100 \mathrm{~g} \mathrm{ha}^{-1}\right)$ for hybrid P30F53 and did not occur in 'BRS 1030' (Table 1).

There were also increases on the levels of $\beta$-cryptoxanthin and $\beta$-carotene (foramsulfuron + iodosulfuron-methyl-sodium, late application), $\alpha$-carotene (foramsulfuron + iodosulfuron-methyl-sodium and tembotrione $80 \mathrm{~g} \mathrm{ha}^{-1}$, on late application), and Pro VA $\left(\mu \mathrm{g} \mathrm{g}^{-1}\right.$ ) (foramsulfuron + iodosulfuron-methyl-sodium, late application), compared to the control, and all of them with means statistically higher for the 'P30F53' compared to the 'BRS 1030' (Tables 1 and 2). This result is interesting because not only mesotrione and tembotrione, which act directly in the biosynthesis of carotenoids, increase the levels of carotenoids in green corn kernel, but the other herbicides like foramsulfuron + iodosulfuron-methyl-sodium, also affected this accumulation. This latter herbicide belongs to the group of the ALS inhibitors (aceto lactate synthase), an enzyme directly involved in the synthesis of valine, leucine and isoleucine amino acids, which are precursors of 3-Hydroxy-3-methylglutanyl-CoA (HMG $\mathrm{CoA}$ ) in the path of mevalonate (Konstantinopoulos et al., 2007). The HMG CoA is correlated with the formation of geranylgeranyl-pyrophosphate (GGPP) the precursor of the phytoene in the biosynthesis of carotenoids. In other words, both pathways are related. 
The accumulation of zeaxanthin for all herbicides applications (Table 1) was higher in 'BRS 1030' than in 'P30F53', explained by the action of enzymes involved in partitioning of the carotenoids biosynthesis pathway after the accumulation of lycopene (Figure 1). The formation of the other carotenoids is directly related to the presence of Blcy (beta lycopene cyclase) and Elcy (epsilon lycopene cyclase) genes, which are responsible for accumulation of zeaxanthin and lutein, respectively (Harjes et al., 2008). Despite the possibility of an increase of carotenoids by the accumulation of lycopene, there are no studies indicating the effect of herbicides specifically in Blcy and Elcy genes for targeting the pathway to the accumulation of a specific fraction of carotenoid of greatest interest.

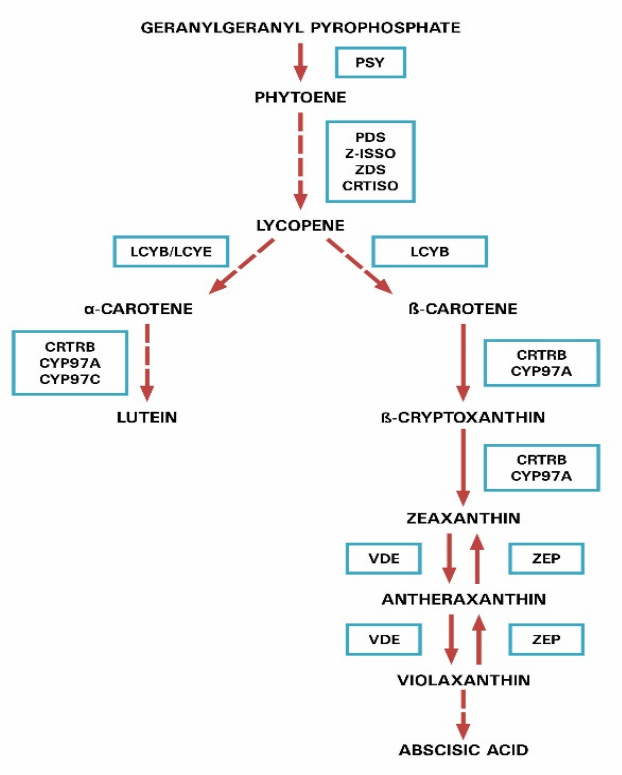

Figure 1. Carotenoid biosynthesis in plants: the route shows the main steps found in almost all plant species. PSY: phytoene sintase; PDS: phytoene desaturase; Z-ISSO: z-carotene isomerase; ZDS: z-carotene desaturase; CRTISO: carotenoid isomerase; LCYB: lycopene b-cyclase; LCYE: lycopene e-cyclase; CRTRB: CYP97A: b-carotene hydroxylase (P450); CYP97C: e-carotene hydroxylase (P450).

\section{Conclusions}

The application of post-emergent herbicides foramsulfuron + iodosulfuron-methyl-sodium, nicosulfuron, mesotrione and tembotrione does not reduce the levels of carotenoids of importance for human consumption, in green corn. Eventhoug the physiological mechanisms involved in this response are still unknown, our results suggest a possibility of significant increase of carotenoids in green corn kernels through the handling of corn production with post-emergent herbicides. In addition, the amount of these carotenoids, mainly xanthophylls, is different among hybrids with or without the application of the post-emergent herbicides, characterizing the effect of genotype on the profile of these compounds.

\section{Acknowledgments}

The authors thank the Harvest Plus and Embrapa (Brazilian Agriculture Research System) for funding theses research activities.

\section{References}

CARDOSO, W. S.; PAES, M. C. D.; GALVÃO, J. C. C.; RIOS, S. A.; GUIMARÃES, P. E. O.; SCHAFFERT, R. E.; BORÉM, A. Variabilidade de genótipos de milho quanto à composição de carotenoides nos grãos. Pesquisa Agropecuária Brasileira, Brasília, DF, v. 44, n. 2, p. 164-173, 2009. DOI: 10.1590/S0100-204X2009000200008.

CONSTANTIN, J.; OLIVEIRA JÚNIOR, R. S. Dessecação antecedendo a semeadura direta pode afetar a produtividade. Informações Agronômicas, Piracicaba, v. 109, p. 14-15, 2005. Available at: $<$ http://www.dag.uem.br/napd/up/Public-NAPD_ a3e0dfd62b3b9192c52eea4cc9bdaefdAm0Cu.pdf > . 
Accessed on: 03 Feb. 2014.

CRUZ, C. D. Programa Genes: biometria. Viçosa, MG: UFV, 2006. 382 p.

FAO. Vitamin A. In: FAO: Human vitamin and mineral requirements. Roma, 2002. Available at: <http://www. fao.org/docrep/004/y2809e/y2809e0d.htm\#bm13>. Accessed on: 10 June 2013.

GE, X. X.; XING, M. Y.; YU, L. F.; SHEN, P. Carotenoid intake and esophageal cancer risk: a meta-analysis. Asian Pacific Journal of Cancer Prevention, v. 14, n. 3, p. 19111918, 2013. Available at: <http://dx.doi.org/10.7314/ APJCP.2013.14.3.1911>. Accessed on: 10 June 2013. DOI: 10.7314/APJCP.2013.14.3.1911.

HARJES, C. E.; ROCHEFORD, T. R.; BAI, L.; BRUTNELL, T.; KANDIANIS, C. B.; SOWINSKI, S. G.; STAPLETON, A. E.; VALLABHANENI, R.; WILLIAMS, M.; WURTZEL, E. T.; YAN, J.; BUCKLER, E. S. Natural genetic variation in lycopene epsilon cyclase tapped for maize biofortification. Science, Washington, v. 319, n. 5861, p. 330-333, 2008. DOI: $10.1126 /$ science. 1150255 .

KARAM, D.; OLIVEIRA, M. F. de; PEREIRA FILHO, I. A.; JESUS, L. L. Sensibilidade de híbridos de milho e herbicidas pós-emergentes aplicados em dois estádios fenológicos da cultura. In: CONGRESSO NACIONAL DE MILHO E SORGO, 27.; SIMPOSIO BRASILEIRO SOBRE A LAGARTA-DO-CARTUCHO, SPODOPTERA FRUGIPERDA, 3.; WORKSHOP SOBRE MANEJO E ETIOLOGIA DA MANCHA BRANCA DO MILHO, 2008, Londrina. Agroenergia, produção de alimentos e mudanças climáticas: desafios para milho e sorgo: trabalhos e palestras. [Londrina]: IAPAR; [Sete Lagoas]: Embrapa Milho e Sorgo, 2008. 1 CD-ROM.

KARAM, D.; OLIVEIRA, M. F. de. Seletividade de herbicidas na cultura do milho. Sete Lagoas: Embrapa Milho e Sorgo, 2007. 8 p. (Embrapa Milho e Sorgo. Circular técnica, 98). Available at: <http://www.cnpms. embrapa.br/publicacoes/publica/2007/circular/Circ_98. pdf $>$. Accessed on: 10 June 2013.
KIM, J.; DELLAPENNA, D. Defining the primary route for lutein synthesis in plants: the role of Arabidopsis carotenoid beta-ring hydroxylase CYP97A3. Proceedings of the National Academy of Sciences of the United States of America, Washington, v. 103, n. 9, p. 3474-3479, 2006. Available at: <http://www.ncbi.nlm.nih.gov/pmc/articles/ PMC1413914/>. Accessed on: 15 May 2012.

DOI: $10.1073 /$ pnas.0511207103.

KONSTANTINOPOULOS, P. A.; KARAMOUZIS, M. V.; PAPAVASSILIOU, A. G.; Post-translational modifications and regulation of the RAS superfamily of GTPases as anticancer targets. Nature Reviews. Drug Discovery, London, v. 6, n. 7, p. 541-555, 2007.

DOI: $10.1038 / \mathrm{nrd} 2221$.

KOPSELL, D. A.; ARMEL, G. R.; MUELLER, T. C.; SAMS, C. E.; DEYTON, D. E.; McELROY, J. S.; KOPSELL, D. E. Increase in nutritionally important sweet corn kernel carotenoides following mesotrione and atrazine applications. Journal of Agricultural and Food Chemistry, Easton, v. 57, p. 6362-6368, 2009.

DOI: $10.1021 / \mathrm{j} f 9013313$.

KURILICH, A. C.; JUVIK, J. A. Quantification of carotenoids and tocopherol antioxidants in Zea mays. Journal of Agricultural and Food Chemistry, Easton, v. 47, n. 5, p. 1948-1955, 1999. DOI: $10.1021 / \mathrm{jf} 981029 \mathrm{~d}$.

LI, F.; MURILlO, C.; WURTZEL, E. T. Maize Y9 encodes a product essential for 15-cis-\{zeta\}-carotene isomerization. Plant Physiology, Bethesda, v. 144, n. 2, p. 1181-1189, 2007. Available at: <http://www.ncbi.nlm.nih. gov/pmc/articles/PMC1914175/>. Accessed on: 15 May 2013. DOI: 10.1104/pp.107.098996.

LICHTENTHALER, H. K.; SCHWENDER, J.; DISCH, A.; ROHMER, M. Biosynthesis of isoprenoids in higher plant chloroplasts proceeds via mevalonate-independent pathway. FEBS Letters, Amsterdam, v. 400, n. 3, p. 271274, 1997. Available at: <http://dx.doi.org/10.1016/S00145793(96)01404-4>. Accessed on: 30 Oct. 2013. DOI: 10.1016/S0014-5793(96)01404-4. 
LÓPEZ-OVEJERO, R. F.; FANCELLI, A. L.; DOURADO NETO, D.; GARCIA Y GARCIA, A.; CHRISTOFFOLETI, P. J. Seletividade de herbicidas para a cultura de milho (Zea mays) aplicados em diferentes estádios fenológicos da cultura. Planta Daninha, Rio de Janeiro, v. 21, n. 3, p. 413-419, 2003. Available at: <http://dx.doi.org/10.1590/ S0100-83582003000300009>. Accessed on: 15 July 2013. DOI: $10.1590 / \mathrm{S} 0100-83582003000300009$.

MAGAlHÃES, P. C.; DURÃES, F. O. M.; CARNEIRO, N. P.; PAIVA, E. Fisiologia do milho. Sete Lagoas: Embrapa Milho e Sorgo, 2002. 23 p. (Embrapa Milho e Sorgo. Circular Tecnica, 22). Available at: $<\mathrm{http}: / / \mathrm{www}$. cnpms.embrapa.br/publicacoes/publica/2002/circular/ Circ_22.pdf>. Accessed on: 06 Feb. 2013.

MITCHELL, G. D. W.; BARTLETT, T. E. M.; FRASER, T. R.; HAWKES, D. C.; HOLT, J. K.; TOWNSON, M.; WICHERT, R. A.; Mesotrione: a new selective herbicide for use in maize. Pest Management Science, Sussex, v. 57, n. 2, p. 120-128, 2001. DOI: $\quad 10.1002 / 1526-4998(200102) 57: 2<120:: A I D-$ PS254>3.0.CO;2-E.

PATAKY, J. K.; MEYER, M.; BOLLMAN, J. D.; BOERBOOM, C. M.; WILliAM, M. M. Genetic basis for varied levels of injury to sweet corn hybrids from three cytochrome P450-metabolized herbicides. Journal of the American Society for Horticultural Science, Alexandria, v. 133, n. 3, p. 438-447, 2008. Available at: <http://journal.ashspublications.org/ content/133/3/438.full.pdf>. Accessed on: 09 Jan. 2013.

PIZARRO, L.; STANGE, C. Light-dependent regulation of carotenoid biosynthesis in plants. Ciencia y Investigación Agraria, Santiago, v. 36, n. 2, p. 143-162, 2009. Available at: $<$ http://www.scielo.cl/scielo.php?script=sci arttext\&pid=S0718-16202009000200001\&lng=es\&nrm=i so $>$. Accessed on: 30 Oct. 2013.

DOI: $10.4067 / \mathrm{S} 0718-16202009000200001$.

RODRIGUEZ-AMAYA, D. B.; KIMURA, M. HarvestPlus handbook for carotenoid analysis. Washington: IFPRI;
Cali: CIAT, 2004. 58 p. (HarvestPlus Technical Monograph, 2). Available at: <http://www.ifpri.org/sites/default/files/ publications/hptech02.pdf $>$. Accessed on: 06 Jan. 2014.

SCHULTZ,A.; ORT, O.; BEYER, P.; KLEINIG, H. SC-0051, A 2-benzoyl-cyclohexane-1,3-dione bleaching herbicide, is a potent inhibitor of the enzyme $p$-hydroxyphenylpyruvate dioxygenase. FEBS Letters, Amsterdam, v. 318, n. 2, p. 161166, 1993. Available at: <http://dx.doi.org/10.1016/00145793(93)80013-K>. Accessed on: 10 Jan. 2013. DOI: 10.1016/0014-5793(93)80013-K.

SCHWENDER, J.; SEEMANN, M.; LICHTENTHALER, H. K.; ROHMER, M. Biosynthesis of isoprenoids (carotenoids, sterols, prenyl side-chains of chlorophylls and plastoquinone) via a novel pyruva-te/glcyeraldehydes 3-phosphate non-mevalonate pathway in the green alga Scenedesmus obliquus. Biochemical Journal, London, v. 316, p. 73-80, 1996. Available at: <http://www.ncbi.nlm. nih.gov/pmc/articles/PMC1217352/pdf/8645235.pdf>. Accessed on: 15 Mar. 2012.

USDA. National Nutrient Database for Standard Reference Release 28. Available at: <http://ndb.nal.usda.gov/ndb/ foods/show $/ 2980$ ? $\mathrm{fg}=$ Vegetables + and + Vegetable+Product $\mathrm{s} \& \operatorname{man}=\&$ lfacet $=\&$ count $=\& \max =25 \&$ sort $=\&$ lookup $=$ cor n\&offset $=\&$ format $=$ Full $\&$ new $=\&$ measureby $=>$. Accessed on: 15 May 2013.

VALLABHANENI, R.; WURTZEL, E. T. Timing and biosynthetic potential for carotenoid accumulation in genetically diverse germplasm of maize. Plant Physiology, Bethesda, v. 150, n. 2, p. 562-572, 2009. DOI: 10.1104/pp.109.137042.

YAO, Y.; QIU, Q.-H.; WU, X.-W.; CAI, Z.-Y.; $\mathrm{XU}, \quad$ S.; LIANG, X.-Q. Lutein supplementation improves visual performance in Chinese drivers: 1-year randomized, double-blind, placebo-controlled study. Nutrition, v. 29, n. 7, p. 958-964, 2013. Available at: <http://www.nutritionjrnl.com/ article/S0899-9007(12)00428-5/pdf $>$. Accessed on: 10 June 2013. doi: 10.1016/j.nut.2012. DOI: $\quad 10.1016 /$ j.nut.2012.10.017. 